EUROPEAN HONORS COUNCIL

Note

\title{
Honours Graduation Day; Measuring Success of Recruitment and Awareness of the Honours Star Programme
}

\author{
Dorine Tamis ${ }^{1}$, Erik Puik ${ }^{2}$
}

1. Manager HBO-ICT / Honours Coordinator FNT, HU University of Applied Sciences Utrecht, The Netherlands, dorine.tamis@hu.nl

2. Professor of Microsystems Technology, HU University of Applied Sciences Utrecht, The Netherlands, erik.puik@hu.nl

Received: 3 February 2017; Accepted: 29 March 2017; Published: 21 April 2017

Keywords: honours certificate, honours star system, graduation

\section{Introduction}

The Faculty of Applied Science and Technology (FNT) at HU University of Applied Sciences Utrecht in The Netherlands offers various challenging honours tracks additional to the regular bachelor programmes. How do we inspire (new) students and teachers to join these honours tracks, and get familiar with the procedure and diversity of the honours tracks that are gathered under the official name 'Honours Star System' at HU University of Applied Sciences?

Of course, we can explain the honours star system and show students and teachers our information booklet and websites with nice examples and ask them to read it. With one of Benjamin Franklin's quotes in mind 'Tell me and I forget, teach me and I may remember, involve me and I learn', the University has chosen a different approach. In 2014 the University initiated two yearly events to which all students and teachers are invited:

- the Honours Graduation Day (HGD) in autumn, and;

- the Honours Information Day (HID) in spring.

The main focus of the Honours Graduation Day is on handing out the HU honours certificates to the participating students from the past college year who received five stars. Note that this is a ceremony apart from the Bachelor degree graduation, during which students receive their Bachelor certificate. The Honours Information Day focuses on the HU honours system itself (Unck, 2016) and on handing out the 'HU honours star certificates', to officially confirm successful completion of one of the tracks. During the events, students and teachers will feel the honours experience and can get in contact with current and former honours students.

\section{Methods}

A dedicated event manager is appointed to organise both events in a professional way, e.g. by using a detailed event script. All participants are asked to fill in an evaluation form. 


\subsection{Event Preparation}

An attractive email invitation is sent to all students and teachers. Flyers, posters and honours booklets are distributed, information is tweeted and announcements are being displayed on digital screens in college buildings. Some students and teachers receive a personal invitation and the events are integrated in the timetables of both students and teachers.

\subsection{Event Programme}

During the events, we celebrate honours. Students receive their HU honours certificates and/or star certificates in a festive ambience. The honours students tell their own personal stories and share their learning experiences and achievements. Students and teachers can meet with the honours students, the audience is invited to speed date with honours committees and present their own ideas. Immediate feedback is given. Keynote speaker at each event is an Executive Board member, relating honours to the overall institutional vision of education (HU University of Applied Sciences Utrecht, 2015). The employers' perspective is not forgotten. Employers are present to give their view on honours and the qualities they are looking for in young employees. Challenging questions are asked in a lively and creative setting. The programme also includes an honours market with information, food and drinks.

\subsection{Event Follow-up}

All students and teachers receive a thank you mail with a link to the website with the event photos, videos and the results of the evaluation forms. The organisers evaluate the events as well, list the key success factors and lessons learned, and update the event script.

\section{Results}

The evaluation form scores, the number of attendees and the number of evaluation forms handed in are presented below in Table 1.

Table 1 Evaluation Results

\begin{tabular}{|l|l|l|}
\hline & $\begin{array}{l}\text { Honours } \\
\text { Graduation Day } \\
2014\end{array}$ & $\begin{array}{l}\text { Honours } \\
\text { Information Day } \\
2015\end{array}$ \\
\hline Attendees & 146 & 280 \\
\hline Evaluation Forms handed in & 56 & 74 \\
\hline Event Score (1-10) & 7.8 & 8 \\
\hline Better Understanding Honours - Yes & $65 \%$ & $99 \%$ \\
\hline $\begin{array}{l}\text { Immediate Registration Honours - } \\
\text { Students (intake for new start courses) }\end{array}$ & 17 & 34 \\
\hline
\end{tabular}

Additional comments - Honours Graduation Day 2014:

- More personal stories students welcome

- More information about content / time spent needed

- Too long 
Additional comments - Honours Information Day 2015:

- Inspiring!

- $\quad$ Everything is more clear now

- Video did not work in one of the rooms

The Honours Graduation Day 2015 was attended by 120 people and unfortunately no evaluation forms were distributed. Compared to the previous events, it can be said that more honours students were present, but fewer teachers. Nine students received their HU honours certificate, whereas 30 students received one or more HU honours star certificates. For the first time, parents were present as well.

\section{Discussion and conclusions}

What has been the inspirational impact of these events? Did students feel inspired to participate in honours as a result of their attendance? How did teachers respond?

The evaluation form scores show that attendees highly appreciated the events and that they gained a better understanding of honours. A number of students immediately joined honours tracks during the events. From 2014 the event focus has gradually changed from informing students and teachers to more sharing personal stories ('We are curious to find out what the students have done and what they have learned').

Some general conclusions can be drawn while evaluating our experience. Below we list the most important key success factors and lessons learned.

Key success factors are:

- $\quad$ Students and teachers feel inspired by personal student stories.

- $\quad$ Honours students appreciate sharing experiences and receiving certificates.

- $\quad$ Students want to get as much practical information as possible, i.e. time needed, number of courses, teachers involved.

- $\quad$ Students and teachers appreciate employers presenting their view on honours.

The most important lessons learned are:

- Integrate these events in the timetables.

- $\quad$ Teachers would like to have more information on how and when they can offer more (honours) challenges to the students.

- Measuring the inspirational impact of the events should be improved.

- $\quad$ Continue to organise these events in a professional way using evaluation forms.

In the coming years, the Honours Graduation Day and the Honours Information Day will be continued. General feedback like attendance and satisfaction will be monitored. The intention is to correlate the growth of the honours programme to this feedback.

\section{References}

HU University of Applied Sciences Utrecht (2015). Our world of tomorrow - Vision of education. Unpublished document, HU University of Applied Sciences Utrecht, Utrecht. 
Page 4 of 4

Unck, S. (2016). HU Honours 2015 - 2020 Onderwijsconcept voor ambitieuze studenten.

Unpublished document, HU University of Applied Sciences Utrecht, Utrecht. 